\title{
ANALISIS RAGAM BAHASA SISWA KELAS X H SMA NEGERI 2 KOTA BENGKULU DI FACEBOOK (KAJIAN SOSIOLINGIUISTIK)
}

\author{
Yunial Fahmi \\ yunialfahmi9@gmail.com \\ Guru SMA Negeri 2 Kota Bengkulu
}

\begin{abstract}
This research is aimed to obtain a descriptive about Analysis of Various Students' Language of Class X H SMA Negeri 2 Bengkulu City Used in Their Facebook of the this research is about how the theme of students' sentences status in their Facebook are, what kind of language and non-language characteristic $s$ of their sentences status in Facebook of students class $X H$ are the research. The data that are collected use purposive sampling technic by taking the samples from sentence status of the students' Facebook accounts which have been collected. The technics used in data analysis are : (1) data collecting, data presenting, (2) conclusion or verification in document. The research findings are guile diverse themes that emerge, but in a sense more positive tone expression (91,6\%) consisting of : interaction, special interaction, expression activity, adage, expression of feeling, expression of feelings provoke cancern, the phrase specifically, and information. While the expression of negative feelings (8,3\%). Likewise, the original identity (the original name of the account status) consists of 19 students with a percentage $(79,1 \%)$ and the remaining 5 students with a pseudonym identity (account status pseudonym) by percentage (20,8\%). Linguistic traits often arises is the use of regional languages, although there are also English-speaking. Non-linguistic traits characterized by the use of icons/symbols (stiker's or emotion) which describes the feeling.
\end{abstract}

Keywords: language variety, Facebook, sociolinguistics

\section{PENDAHULUAN}

Saat ini perkembangan dunia semakin maju pesat. Perkembangan yang sangat pesat ini juga merambah pada perkembangan media massa. Oleh karena adanya pekembangan media massa tersebut maka banyak sekali masyarakat yang menggunakan media massa sebagai media penyampai suatu pesan atau informasi ke masyarakat luas, salah satunya yaitu para siswa sebagai kaum muda. Di era globalisasi ini bahasa Indonesia yang baik dan benar semakin jarang dipakai terutama dikalangan remaja, seiring perkembangan zaman muncullah modifikasi gaya bahasa menjadi bahasa gaul. Hal ini dipengaruhi juga oleh semakin berkembangnya teknologi, terutama berkembangnya situs jejaring sosial, seperti Facebook, email, twitter dan lain-lain. Facebook adalah sebuah media jejaring sosial yang sedang digandrungi oleh masyarakat dunia, termasuk Indonesia.

Dari segi usia, Facebook terbilang masih muda dibandingkan dengan myspace atau friendster yang juga bergerak di bidang yang sama, yaitu media jejaring sosial. Dalam laman Wikipedia disebutkan bahwa Facebook, 
secara resmi, diluncurkan pada tanggal 4 Februari 2004 di Cambridge, Amerika Serikat. Pada awalnya, Facebook adalah sebuah program penyedia buku panduan, pada Philip Exeter Academy tempat Zuckerberg menimba ilmu. Laman itu lebih dikenal dengan sebutan "face book". Kemudian, pada saat Zuckerberg berkuliah di Universitas Harvard, ia dan tiga orang temannya mengembangkan konsep "face book" menjadi sebuah media pertemanan bagi mahasiswa Universitas Harvard. Tanpa disengaja, Facebook berkembang dengan pesat ke seluruh dunia. Di bawah naungan Facebook.Inc. sekarang Facebook memiliki omset lebih dari 300 juta dolar dengan pekerja lebih dari 1400 orang. Dari jaringan sosial Facebook, bahasa terus berkembang dan digunakan untuk berkomunikasi dan pertemanan di media sosial.

Bahasa adalah salah satu ciri yang paling khas manusiawi yang membedakannya dengan makhlukmakhluk lain, dengan bahasa manusia mampu mengemukakan dan sekaligus mengekspresikan pendapat, ide, gagasan dan emosinya. Tak ada manusia atau masyarakat di dunia ini mampu berkembang tanpa bahasa.

Sosiolinguistik merupakan ilmu antardisiplin antara sosiologi dan linguistik, dua bidang ilmu empiris yang mempunyai kaitan sangat erat. Kita harus memahami kedua disiplin ilmu tersebut. Menurut Nababan dalam Chaer dan Agustina(2004:3) Pengkajian bahasa dengan dimensi kemasyarakatan disebut sosiolinguistik. Sosiolinguistik menempatkan kedudukan bahasa dalam hubungannya dengan pemakaian bahasa dalam masyarakat. Hal ini menunjukkan bahwa sosiolinguistik memandang bahasa sebagai sistem sosial dan sistem komunikasi serta merupakan bagian dari masyarakat dan kebudayaan. Komunikasi telah memperpendek jarak, menghemat biaya, menembus ruang dan waktu. Komunikasi berusaha menjembatani antara pikiran, perasaan dan kebutuhan seseorang dengan dunia luarnya.

Dari beberapa pengertian di atas tentu saja sosiolinguistik dan ilmu komunikasi mengarah pada benang merah penelitian bahasa dan masyarakat pengguna bahasa, yang dalam hal ini, ragam atau variasi bahasa yang terdapat di Facebook sangat menarik untuk dijadikan bahan penelitian lebih jauh dan mendalam.

Berdasarkan uraian di atas, penulis tertarik untuk membahas tema dari variasi atau ragam bahasa Facebook siswa SMA Negeri 2 Kota Bengkulu. Hal tersebut juga akan mengarah pada ciri kebahasaan dan nonkebahasaan pemakaian bahasa Facebook siswa SMA Negeri 2 Kota Bengkulu.

Aktivitas siswa SMA kelas $\mathrm{X} \mathrm{H}$ SMA Negeri 2 Kota Bengkulu di Facebook merupakan suatu aktivitas yang rutin dan siswa SMA menggunakan bahasa yang khas dan merupakan variasi bahasa berdasarkan pemakainya atau disebut dengan register. Penggunaan bahasa yang khas itu terdiri dari kosa kata atau istilah yang dipakai di Facebook dan hanya dapat dipahami bagi yang ikut berkecimpung dalam aktivitas yang berhubungan dalam pertemanan. Dari ulasan tersebut peneliti memfokuskan untuk mengungkapkan apa sajakah tema yang biasa diungkapkan dalam tulisantulisan atau kalimat-kalimat status siswa siswi tersebut dan hal-hal seperti ciri-ciri kebahasaan berupa kosa kata, singkatan/akronim, dan aspek sosial 
teks/teks, serta ciri nonkebahasaan yang mengarah pada tanda baca, semiotika/makna yang berupa symbol/tanda penggunaan bahasa dalam Facebook siswa kelas X H SMA Negeri 2 Kota Bengkulu.

\section{METODE PENELITIAN}

Metode penelitian ini menggunakan metode deskripstif, dan dilakukan dengan cara mencatat, mengamati langsung pada teks Facebook yang di print out oleh siswa/i, penelitian dalam waktu yang ditentukan sehingga peneliti dapat mendeskripsikan secara jelas tentang register atau variasi bahasa yang digunakan oleh siswa dalam status kalimat Facebook. Sumber data dalam penelitian ini ada dua, yaitu: (1). Tempat/lokasi. Tempat dan lokasi yang berkaitan dengan sasaran penelitian, yaitu SMA Negeri 2 Kota Bengkulu khususnya siswa kelas X H. (2) Dokumen. Dokumen yang dimaksud disini adalah hasil print out Akun/Facebook siswa yang berjumlah 24 dari 30 siswa dalam satu kelas, jadi terdapat 6 siswa yang tidak mempunyai Akun/Facebook atau tidak mengumpulkan print out Akun/Facebook nya.

Teknik pengumpulan data yang diterapkan sebagai alat untuk menjaring data secara lengkap dan akurat sehubungan dengan masalah yang diteliti. Penelitian ini memakai 2 teknik, yaitu :(1) teknik pengamatan langsung, (2) teknik analisis dokumen.

Teknik pengamatan langsung diterapkan untuk memperoleh deskripsi mengenai proses kegiatan tindak tutur beserta pemahaman konteks dan komponen yang mempengaruhi kegiatan tindak tutur tersebut, antara lain: Siapa penutur, dimana kegiatan berlangsung, kapan kegiatan berlangsung, dan apa tujuan dari tindak tutur tersebut. Maksud dari mendeskripsikan data adalah menggambarkan data yang ada guna memperoleh bentuk nyata dari responden, sehingga lebih mudah dimengerti (Sukardi, 2004:86). Hal ini dilakukan dengan asumsi bahwa kegiatan mengamati yang terjadi seringkali jauh lebih baik dan lengkap. Teknik analisis dokumen dilakukan dengan transkrip dan menganalisis data yang berupa data print out akun profil Facebook siswa.

Teknik analisis data deskriptif ini bertujuan untuk memberikan deskripsi mengenai subjek penelitian berdasarkan data dari variabel yang diperoleh dari kelompok subjek yang diteliti hal ini sejalan dengan pendapat Azwar (2009:126-127) penelitian ragam bahasa Facebook ini pendekatannya lebih bersifat kualitatif yang penyajian hasil analisis deskriptifnya berupa frekuensi dan persentase.

Penyajian persentase dan proporsi memberikan gambaran mengenai distribusi subjek menurut kategori-kategori nilai variabel. Oleh karena itu, analisis ini didasarkan pada distribusi frekuensi. Secara visual, penggunaan tabel frekuensi sangat membantu memahami keadaan data yang disajikan dalam penelitian ini. Sehingga dengan mudah akan difahami distribusi subjek dari persentase kalimatkalimat akun Facebook siswa siswi tersebut.

\section{HASIL DAN PEMBAHASAN}

Tema status yang banyak dimunculkan menunjukkan kecenderungan pemikiran dan perasaan yang 
dominan di kalangan siswa pengguna Facebook. Data ini dapat dimaknai bermacam-macam. Data ini juga dapat dijadikan dasar pengkajian bidang lain, seperti psikologi dan sosiologi, terlebih lagi sosiolinguistik. Berikut ini adalah data hasil penelitian dalam analisis tabel data sebagai berikut:

Tabel 1. Kalimat Interaksi (Int)

\begin{tabular}{|l|l|l|l|l|}
\hline \multirow{2}{*}{ No } & \multicolumn{2}{|c|}{ Tema } & \multicolumn{1}{c|}{ Kalimat Status } & \multicolumn{2}{c|}{ Status Akun } \\
\cline { 4 - 5 } & $\begin{array}{l}\text { 1. } \\
\text { Interaksi(Int) }\end{array}$ & $\begin{array}{l}\text { 1.Hahaha, belajar ngedit yong :) ol diman } \\
\text { yong? Dak dimarah gaek?? (Int 1) } \\
\text { 23.Nyo tu dak banyak ulah pak....(Int 2) }\end{array}$ & $\begin{array}{c}\text { 1. ya } \\
\text { Samaran }\end{array}$ \\
\hline 23. ya & \\
\hline
\end{tabular}

Keterangan:

Berdasarkan kalimat status yang dituliskan dalam akun Facebook, dari dua siswa tersebut, kalimat status (1) tema kalimat tersebut mengarah pada kalimat interaksi yang diberi kode (Int 1) diambil dari Lampiran I Tabel I Rekapitulasi Data Akun, Kalimat Status dan Tema. Berdasarkan Lampiran Utama Kalimat Status Akun Facebook. Siswi yang bernama Ade Mentari menggunakan nama akun Facebook Ade Mentari (Tary Cookies Child) menggunakan nama asli dan dijelaskan dengan nama samaran, tetapi dalam hal ini masuk dalam kategori menggunakan nama akun Facebook asli. Sedangkan kalimat status ke dua nomor (23) mengarah pada kalimat interaksi dengan kode (Int 2) dengan menggunakan nama asli tanpa nama samaran yaitu Rofika Tiara Aviesteva.

Tabel 2 Kalimat Interaksi Khusus (IK)

\begin{tabular}{|c|c|c|c|c|}
\hline \multirow[b]{2}{*}{ No } & \multirow[b]{2}{*}{ Tema } & \multirow[b]{2}{*}{ Kalimat Status } & \multicolumn{2}{|c|}{ Status Akun } \\
\hline & & & $\begin{array}{c}\text { Nama } \\
\text { Asli }\end{array}$ & $\begin{array}{c}\text { Nama } \\
\text { Samaran }\end{array}$ \\
\hline 1 & InteraksiKhusus(IK) & $\begin{array}{l}\text { 17. Happy anniversary my lovely } \\
\text { girl...(IK } 1 \text { ) } \\
\text { 20. Makasih ya ucapannya, ditunggu } \\
\text { kadonya...(IK 2) } \\
\text { 21. lagi belajarlah pulo cin, belajar } \\
\text { tugas pak Fahmi hehhe :D (IK 3) }\end{array}$ & 21. ya & 20. ya \\
\hline
\end{tabular}

Keterangan:

Berdasarkan kalimat status yang dituliskan dalam akun Facebook, dari ke tiga siswa siswi tersebut, kalimat ke satu, kalimat status (17) mengarah pada tema kalimat Interaksi Khusus yang diberi kode (IK 1) diambil dari Lampiran I Tabel I Rekapitulasi Data Akun, Kalimat Status dan Tema. Berdasarkan Lampiran Utama Kalimat Status Akun Facebook. Siswa yang bernama Setya Riantama menggunakan nama akun Facebook yang menggunakan nama asli, dalam hal ini masuk dalam kategori menggunakan nama akun Facebook asli. Sedangkan kalimat status ke dua, kalimat (20), 
mengarah pada kalimat Interaksi Khusus (IK 2) dengan menggunakan nama samaran yaitu Terserah Nita. Kalimat ke tiga, kalimat (21) lagi belajarlah pulo cin, belajar tugas pak Fahmi hehhe :D. mengarah kepada kalimat Interaksi Khusus (IK 3). Dengan menggunakan nama akun Facebook nama asli

Tabel 3 Kalimat Ungkapan Perasaan Curhat Negatif (UPCN)

\begin{tabular}{|l|l|l|l|l|}
\hline No & Tema & Kalimat Status & \multicolumn{2}{|l|}{ Status Akun } \\
\cline { 3 - 5 } & & Nama Asli & $\begin{array}{l}\text { Nama } \\
\text { Samaran }\end{array}$ \\
\hline 1 & $\begin{array}{l}\text { Ungkapan } \\
\text { Perasaan Curhat } \\
\text { Negatif } \\
\text { (UPCN) }\end{array}$ & $\begin{array}{l}\text { 2.Terlalu sial... hari ini. (UPCN 1) } \\
\text { 4.Pengen mati aja rasanya :'( (UPCN }\end{array}$ & $1 . \quad$ Ya & \\
4. ya \\
\hline
\end{tabular}

Keterangan:

Berdasarkan kalimat status yang dituliskan dalam akun Facebook, dari ke dua siswa, dua kalimat tersebut mengarah pada kalimat Ungkapan Perasaan Curhat Negatif yang diberi kode (UPCN) diambil dari Lampiran I Tabel I Rekapitulasi Data Akun, Kalimat Status dan Tema. Berdasarkan Lampiran Utama Kalimat Status Akun Facebook. Kalimat pertama nomor (2) (UPCN1)
Siswa yang bernama Adyt Maulidimas menggunakan nama akun Facebook nama asli dan tanpa nama samaran, dalam hal ini masuk dalam kategori menggunakan nama akun Facebook asli. Sedangkan kalimat status ke dua nomor (4) mengarah pada kalimat Ungkapan Perasaan Curhat Negatif dengan kode (UPCN 2) dengan menggunakan nama samaran yaitu Arthaz Hue.

Tabel 4 Kalimat Ungkapan Kegiatan (UK)

\begin{tabular}{|l|l|l|l|l|}
\hline \multirow{2}{*}{ No } & \multicolumn{1}{|c|}{ Tema } & \multicolumn{1}{|c|}{ Kalimat Status } & \multicolumn{2}{|c|}{ Status Akun } \\
\cline { 3 - 5 } & \multicolumn{1}{|c|}{$\begin{array}{c}\text { Nama } \\
\text { Samaran }\end{array}$} \\
\hline 1 & $\begin{array}{l}\text { Ungkapan } \\
\text { Kegiatan(UK) }\end{array}$ & $\begin{array}{l}\text { 3.Mandi dulu ah....atuttelat..hahhaa } \\
\text { (UK 1) }\end{array}$ & & 3. Ya \\
\hline
\end{tabular}

Keterangan:

Berdasarkan kalimat status yang dituliskan dalam akun Facebook, dari siswa tersebut, tema kalimat (3) tersebut mengarah pada kalimat Ungkapan Kegiatan yang diberi kode (UK) diambil dari Lampiran I Tabel I Rekapitulasi Data Akun, Kalimat Status dan Tema. Berdasarkan Lampiran Utama Kalimat
Status Akun Facebook. Siswa yang bernama Arky Drew Bieberz menggunakan nama akun Facebook dengan nama samaran, tetapi dalam hal ini masuk dalam kategori menggunakan nama akun Facebook asli, kalimat tersebut dengan kode (UK 1) Sedangkan kalimat status Ungkapan Kegiatan siswa lain tidak ada. 
Tabel 5. Kalimat Ungkapan Bijak (UB)

\begin{tabular}{|c|c|c|c|c|}
\hline \multirow{2}{*}{ No } & \multirow{2}{*}{ Tema } & \multirow{2}{*}{ Kalimat Status } & \multicolumn{2}{|c|}{ Nama Akun } \\
\hline & & & Asli & Samaran \\
\hline 1 & $\begin{array}{l}\text { Ungkapan } \\
\text { Bijak(UB) }\end{array}$ & $\begin{array}{l}\text { 5. (1). When I see you face, there's not a thing } \\
\text { that I would change. (UB 1) } \\
\text { 6. (2). Mudah datang, mudah pergi. Itu hanya } \\
\text { bagaimana kamu hidup. Ambil, ambil, dan } \\
\text { ambil semuanya tapi kau tidak pernah } \\
\text { memberikan jika sudah tahu betapa sulitnya } \\
\text { hidup sebagai manusia hidup (UB 2) } \\
\text { 8. (3). Semua orang tua punya alasan masing- } \\
\text { masing kenapa anaknya nggak boleh pacaran. } \\
\text { Nggak usah nyesel punya orangtua kayak } \\
\text { mereka sayang, mereka punya tujuan yg } \\
\text { bakal kamu tau (UB 3) } \\
\text { 9. (4). Jangan maksain kehendak (UB 4) } \\
\text { 19. (5). Hidup memerlukan perjuangan sesuai } \\
\text { dengan target yang ingin dicapai (UB 5) } \\
\text { 22. (6). Sebaik-baiknya manusia adalah } \\
\text { manusia yang bisa memberikan manfaat } \\
\text { untuk orang lain..(UB 6) }\end{array}$ & $\begin{array}{l}9 . Y a \\
22 . Y a\end{array}$ & 19. Ya \\
\hline
\end{tabular}

Keterangan:

Berdasarkan kalimat status yang dituliskan dalam akun Facebook, dari ke enam siswa tersebut, tema kalimat tersebut mengarah pada kalimat Ungkapan Bijak yang diberi kode (UB) diambil dari Lampiran I Tabel I Rekapitulasi Data Akun, Kalimat Status dan Tema.Berdasarkan Lampiran Utama Kalimat Status Akun Facebook. Siswi yang bernama Desvira Amalia menggunakan nama akun Facebook nama asli, dalam hal ini masuk dalam kategori menggunakan nama akun Facebook asli, dengan kode (UB 1), kalimat ke (5). Sedangkan kalimat status ke dua mengarah pada kalimat Ungkapan Bijak dengan kode (UB 2) nomor (6) dengan menggunakan nama samaran yaitu Diory Besly Malik. Masuk dalam kategori status akun nama samaran. Kalimat ke tiga Ungkapan Bijak dengan kode (UB 3) kalimat nomor (8) menggunakan nama asli Enda Suminar, masuk dalam kategori status akun nama asli. Kalimat ke empat dengan kode (UB 4) nomor (9) dengan Tema kalimat Ungkapan Bijak menggunakan nama asli Eza Wiratama. Kalimat ke lima dengan kode (UB 5) dengan kalimat nomor (19) dengan menggunakan status akun nama samaran Simon Sevenfold. Sedangkan Ungkapan Bijak (UB 6) dengan nomor kalimat (22) menggunakan status akun nama asli yaitu Vike Dianti Putri masuk dalam kategori status nama akun asli.

Tabel 6. Kalimat Ungkapan Perasaan (UP)

\begin{tabular}{|l|l|l|l|l|}
\hline \multirow{2}{*}{ No } & \multirow{2}{*}{ Tema } & \multicolumn{1}{|c|}{ Kalimat Status } & \multicolumn{2}{|c|}{ Nama Akun } \\
\cline { 4 - 5 } & & Asli & Samaran \\
\hline 1 & $\begin{array}{l}\text { Ungkapan } \\
\text { Perasaan(UP) }\end{array}$ & 4. (1) jangan sampai remet galo (UP 1) & 4. Ya & \\
\hline
\end{tabular}




\begin{tabular}{|c|c|c|c|c|}
\hline \multirow{2}{*}{ No } & \multirow{2}{*}{ Tema } & \multirow{2}{*}{ Kalimat Status } & \multicolumn{2}{|c|}{ Nama Akun } \\
\hline & & & Asli & Samaran \\
\hline & & $\begin{array}{l}\text { 15. (2) makasih buat pecahan gelasnya, } \\
\text { patahan nomornya, kertas berpita } \\
\text { merahnya, sama bakpaunya () maaf udh } \\
\text { bikin kamu sakit.(UP2) } \\
\text { 16. (3) Dipagi hari aku makan di jerman, } \\
\text { disiang hari aku istirahat di } \\
\text { spanyol.dimalam hari aku tidur di inggris. } \\
\text { Senangnya menjadi Dipagi hari aku } \\
\text { makan di jerman, disiang hari aku } \\
\text { istirahat di spanyol.dimalam hari aku } \\
\text { tidur di inggris. Senangnya menjadi } \\
\text { seorang RICH (UP 3) } \\
\text { 18 (4) terlalu manis untuk dilupakan (UP } \\
\text { 4) }\end{array}$ & $16 . \mathrm{Ya}$ & \\
\hline
\end{tabular}

Keterangan:

Berdasarkan kalimat status yang dituliskan dalam akun Facebook, dari dua siswa tersebut, tema kalimat tersebut mengarah pada kalimat Ungkapan Perasaan yang diberi kode (UP) diambil dari Lampiran I Tabel I Rekapitulasi Data Akun, Kalimat Status dan Tema. Berdasarkan Lampiran Utama Kalimat Status Akun Facebook. Siswi yang bernama Dona Kartika menggunakan nama asli, dengan kode kalimat status (UP 1) dalam hal ini masuk dalam kategori menggunakan nama akun Facebook asli. Sedangkan kalimat status ke dua mengarah pada Ungkapan Perasaan (UP2) dengan menggunakan nama asli tanpa nama asli yaitu Lidya Permata Sari. Kalimat ke (3) Ungkapan Perasaan dengan kode (UP3) menggunakan nama asli Rich Gemilang. S. Kalimat ke (4) dengan tema status Ungkapan Perasaan kode (UP4) juga menggunakan status akun dengan nama asli Shanti Yohana.

Tabel 7. Kalimat Ungkapan Perasaan Memancing Perhatian (UPMP)

\begin{tabular}{|c|c|c|c|c|}
\hline \multirow[b]{2}{*}{ No } & \multirow[b]{2}{*}{ Tema } & \multirow[b]{2}{*}{ Kalimat Status } & \multicolumn{2}{|c|}{ Status Akun } \\
\hline & & & Nama Asli & $\begin{array}{c}\text { Nama } \\
\text { Samaran }\end{array}$ \\
\hline 1 & $\begin{array}{l}\text { Ungkapan } \\
\text { Perasaan } \\
\text { Memancing } \\
\text { Perhatian(UPMP) }\end{array}$ & $\begin{array}{l}\text { 10. (1) weiweiweiwei (UPMP 1) } \\
\text { 11. (2)yes....') (UPMP 2) } \\
\text { 14. (3)How are you doing? (UPMP 3) } \\
\text { 24. (4) woooy (UPMP 4) }\end{array}$ & $\begin{array}{l}\text { 10. Ya } \\
11 . Y a \\
14 . Y a \\
24 . Y a\end{array}$ & \\
\hline
\end{tabular}

Keterangan:

Berdasarkan kalimat status yang dituliskan dalam akun Facebook, dari dua siswa tersebut, tema kalimat tersebut mengarah pada kalimat Ungkapan
Perasaan Memancing Perhatian yang diberi kode (UPMP) diambil dari Lampiran I Tabel I Rekapitulasi Data Akun, Kalimat Status dan Tema.Berdasarkan Lampiran Utama 
Kalimat Status Akun Facebook. Siswi yang bernama Fanni Indah Permata Sari menggunakan nama akun Facebook nama asli. Dengan kode (UPMP 1) kalimat (10.1). Sedangkan kalimat status ke dua mengarah pada kalimat Ungkapan Perasaan Memancing Perhatian dengan kode (UPMP 2) dengan nomor (11.2) menggunakan nama asli tanpa nama samaran yaitu Gea Nada. Kalimat ke tiga (14.3) tema Ungkapan Perasaan Memancing Perhatian (UPMP 3) menggunakan status akun nama asli yaitu Indria Asrinda. Keterangan kalimat ke empat (24.4) tema Ungkapan perasaan Memancing Perhatian (UPMP 4) menggunakan status akun nama asli Layla Juwita.

Tabel 8. Kalimat Ungkapan Secara khusus (USK)

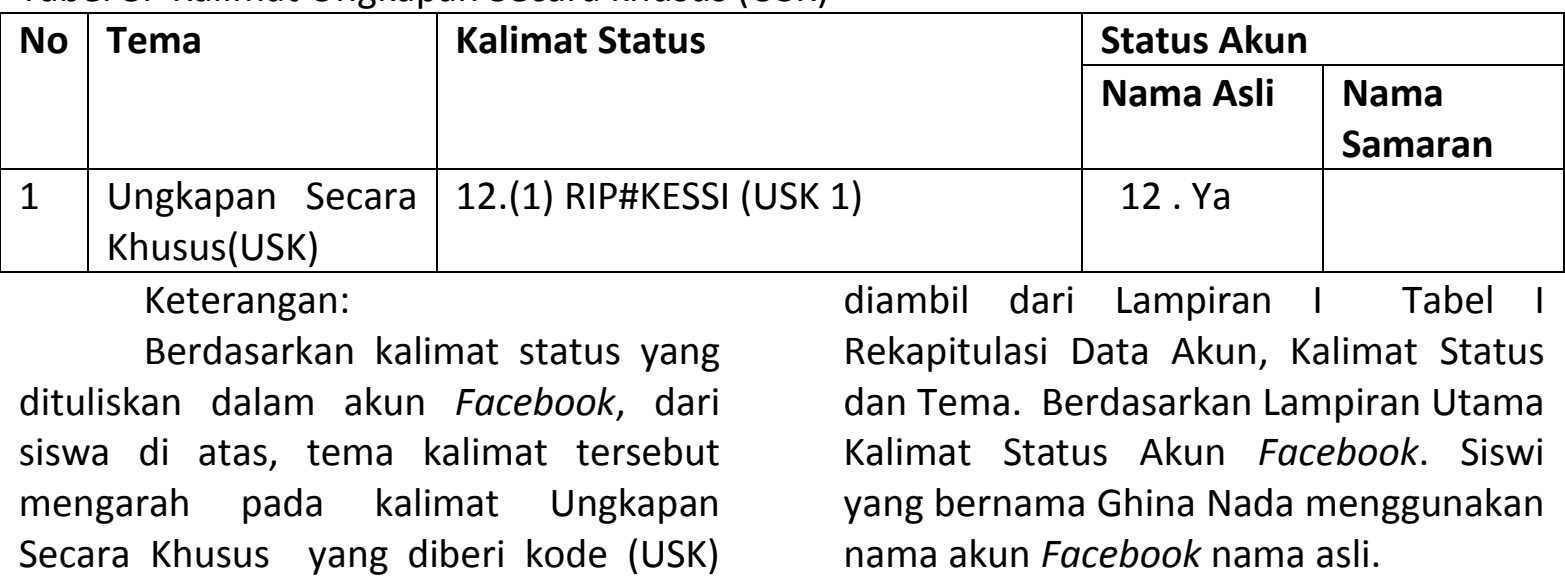

Tabel 9. Kalimat Informasi (Inf)

\begin{tabular}{|l|c|c|c|c|}
\hline \multirow{2}{*}{ No } & \multirow{2}{*}{ Tema } & \multicolumn{1}{|c|}{ Kalimat Status } & \multicolumn{2}{|c|}{ Nama Akun } \\
\cline { 3 - 5 } & & \multicolumn{1}{|c|}{ Asli } & Samaran \\
\hline 1 & Informasi(Inf) & $\begin{array}{l}\text { 13. (1) Aku dan alam adalah satu } \\
\text { (DWIPALA)(Inf 1) }\end{array}$ & 13. Ya & \\
\hline
\end{tabular}

Keterangan:

Berdasarkan kalimat status yang dituliskan dalam akun Facebook, dari siswa tersebut, tema kalimat tersebut mengarah pada kalimat Informasi yang diberi kode (Inf) diambil dari Lampiran I Tabel I Rekapitulasi Data Akun, Kalimat Status dan Tema. Berdasarkan Lampiran
Utama Kalimat Status Akun Facebook. Siswa yang bernama Ilham Kurniawan Ardi menggunakan nama akun Facebook dengan nama asli. Memberikan informasi dalam kalimat status sehingga pertemanan dapat melihat dan merespon serta member tanggapan dari kalimat status tersebut.

Tabel 10. Rekapitulasi Persentase Tema

\begin{tabular}{|l|l|l|l|l|}
\hline No & \multicolumn{1}{|c|}{ TEMA } & \multicolumn{1}{|c|}{ KODE } & \multicolumn{1}{|c|}{$\begin{array}{c}\text { JUMLAH } \\
\text { DATA }\end{array}$} & \multicolumn{1}{|c|}{ PERSENTASE } \\
\hline 1 & Interakasi & Int & 2 & $8,3 \%$ \\
\hline 2 & Interaksi Khusus & IK & 3 & $12,5 \%$ \\
\hline 3 & $\begin{array}{l}\text { Ungkapan Perasaan Curhat } \\
\text { Negatif }\end{array}$ & UPCN & 2 & $8,3 \%$ \\
\hline
\end{tabular}




\begin{tabular}{|l|l|l|l|l|}
\hline No & \multicolumn{1}{|c|}{ TEMA } & \multicolumn{1}{|c|}{ KODE } & \multicolumn{1}{c|}{$\begin{array}{c}\text { JUMLAH } \\
\text { DATA }\end{array}$} & \multicolumn{1}{|c|}{ PERSENTASE } \\
\hline 4 & Ungkapan Kegiatan & UK & 1 & $4,1 \%$ \\
\hline 5 & Ungkapan Bijak & UB & 6 & $25 \%$ \\
\hline 6 & Ungkapan Perasaan & UP & 4 & $16,6 \%$ \\
\hline 7 & $\begin{array}{l}\text { Ungkapan Perasaan } \\
\text { Memancing Perhatian }\end{array}$ & UPMP & 4 & $16,6 \%$ \\
\hline 8 & Ungkapan Secara Khusus & USK & 1 & $4,1 \%$ \\
\hline 9 & Informasi & Inf & 1 & $4,1 \%$ \\
\hline Jumlah Total & & 24 siswa & $100 \%$ \\
\hline
\end{tabular}

Keterangan:

$$
\frac{\text { Jumlah data }}{\text { total sampel }} \times 100 \%
$$

Data di ambil dari lampiran I Tabel 1. Berdasarkan Lampiran 2 Print out data Akun Facebook atau Kalimat akun Facebook siswa siswi yang terdiri dari 24 total sampel, dengan menganalisis kalimat-kalimat yang dianggap mewakili bagian-bagian tersebut. Sehingga di dapat data-data sebagai berikut: Tema yang mengarah pada Interaksi terdiri dari 2 kalimat dengan kode (Int) dibagi jumlah total 24 dan dikalikan $100 \%$ maka akan didapat persentase $8,3 \%$. Tema kalimat yang mengarah pada Interaksi Khusus nomor ke 2 dengan kode (IK) sebanyak tiga kalimat, sehingga 3 dibagi jumlah total 24 siswa lalu dikalikan $100 \%$ maka akan di dapat persentase $12,5 \%$. Tema kalimat Ungkapan Perasaan Curhat Negatif dengan kode (UPCN) sebanyak 2 kalimat, dibagi jumlah total siswa 24 dan dikalikan $100 \%$ sehingga mendapatkan persentase $8,3 \%$. Tema kalimat ke 4 yang mengarah pada Ungkapan Kegiatan dengan kode (UK) dengan jumlah 1 dibagi 24 dan dikalikan $100 \%$ menjadi $4,1 \%$. Tema kalimat dengan nomor lima, Ungkapan Bijak (UB) sebanyak 6 (enam) kalimat dibagi jumlah total siswa 24 kemudian dikalikan 100\% mendapatkan hasil $25 \%$. Kalimat ke enam dengan tema Ungkapan Perasaan dengan kode (UP) didapat jumlah 4 kalimat, sehingga 4 dibagi 24 dan dikalikan 100\% maka didapatkan hasil persentase $16,6 \%$. Kalimat tema Ungkapan Perasaan Memancing Perhatian dengan kode (UPMP) sebanyak 4 tema, berarti empat dibagi 24 dan dikalikan $100 \%$ maka akan didapat persentase $16,6 \%$. Selanjutnya dengan kalimat tema Ungkapan Secara Khusus dengan kode (USK) sebanyak 1 kalimat, sehingga 1 dibagi 24 dan dikalikan $100 \%$ menjadi $4,1 \%$. Dan kalimat tema Informasi dengan kode (Inf) sebanyak satu kalimat, sehinggga 1 dibagi jumlah total sampel 24 dan dibagikan dengan $100 \%$ maka akan didapat hasil persentase $4,1 \%$. 
Tabel 11. Hasil Rekapitulasi Tema

\begin{tabular}{|l|l|l|}
\hline TEMA & VOLUME & PERSENTASE \\
\hline $\begin{array}{l}\text { Ungkapan Bernada Positif } \\
\text { (Tabel 1, 2, 4, 5, 6, 7, 8, dan 9) }\end{array}$ & 22 & $91,6 \%$ \\
\hline $\begin{array}{l}\text { Ungkapan Perasaan Negatif } \\
\text { (UPCN. Tabel 3) }\end{array}$ & 2 & $8,3 \%$ \\
\hline JUMLAH & 24 & $99,9=100 \%$ \\
\hline
\end{tabular}

Tema yang muncul cukup beragam, namun dalam arti lebih banyak Ungkapan Bernada Positif (91,6\%) yang terdiri dari: Interaksi, Interaksi Khusus, Ungkapan Kegiatan, Ungkapan Bijak, Ungkapan Perasaan, Ungkapan Perasaan Memancing Perhatian, Ungkapan Secara Khusus, dan Informasi. Sedangkan Ungkapan Perasaan Negatif (8,3\%).

Demikian juga dengan identitas diri asli ( Status Akun Nama Asli) terdiri dari 19 orang siswa dengan persentase $(79,1 \%)$ dan sisanya 5 siswa dengan identitas samaran (Status Akun Nama Samaran) dengan persentase $(20,8 \%)$

\section{Ciri-Ciri Kebahasaan} a Kosakata

Kosakata diartikan sebagai, "perbendaharaan kata".Contoh penggunaan kosakata ragam bahasa yang digunakan siswa yang merupakan khas Bengkulu sebagai Berikut:
(1) Amb
'ambo (saya atau aku)
(2) Nyemak 'kotor
(3) Male 'malas
(4) Nido 'tidak
(5) Lemak 'enak
(6) Ndak 'ingin
(7) Gawe 'kerja
(8) Ngamuk 'marah
(9) Dewek 'sendiri

(10) Caknyo 'sepertinya

Kosakata khas ini berasal dari Bengkulu dari Bahasa Daerah Kota Bengkulu, bahasa Daerah Manna
Kabupaten Bengkulu Selatan dan ada juga bahasa dari daerah lain, seperti campuran bahasa Palembang yang merupakan Kreatifitas Siswa Kelas X RSBI H SMA Negeri 2 Kota Bengkulu dalam membuat kosa kata. Hal ini sudah menjadi suatu kebiasaan bagi siswa untuk menuliskan bahasa lisan di media, khususnya media Facebook. Sehingga menjadi bahasa tulis.

\section{b. Aspek Sosial Teks}

1. Percakapan Ade Melati (AM) dan Desvira Amalia (DA)

AM : ira

DA : apo say? Weis pp hasil editan dwek yo...

AM : hahaha, belajar ngedit yong )) ol dimn yong? Dak d mrh gaek ?

DA : sipsip ol dirumah dhe. Idak kok.. kau?

AM : warnet dung yong :D caknyo lagi banyak pulsa ko ?

DA : oo, apo alasan kewarnet tadi?:D kek ayuk? Wkwk...

AM :cari tugas :D hahaha iyo dong, dak berani amb Dwek"an. Amb sekalian ndak buek tugas b.i yong :D ... udah mkn yong?

Analisis aspek sosial teks yang terdapat dalam kalimat di atas antara lain dapat dilihat dari kalimat awal yaitu sapaan terhadap temannya "Ira" berarti mengharapkan Ira atau Desvira Amalia 
untuk membalas sapaan tersebut. Maka akan terjadi komunikasi dan interaksi dari kedua siswi tersebut. Selanjutnya kalimat "apo say? Weis pp hasil editan dwek yo..." menggambarkan bahwa ungkapan bukan sekedar basa-basi, tetapi memberikan gambaran bahwa ada makna di luar teks yang mengindikasikan bahwa mereka sedang membahas masalah 'pengeditan' atau mengedit tugas di rumah. Diksi atau pilihan kata bertanya selanjutnya mengedit di mana menjadi kelanjutan percakapan, dalam kalimat tersebut ada modus keraguan 'edit' di rumah atau bukan, sehingga ada jawaban 'edit tugas' di warnet karena lagi banyak pulsa. Relasi atau hubungan pembicara diantara mereka berdua mengindikasikan pertemanan yang sudah akrab.Fungsi bahasanya saling tukar informasi tentang keadaan, situasi kondisi diantara kedua pihak. Dialog tersebut saling sambung menyambung, saling mengerti secara kohesi dan koherensinya (satu dan padu)

2. Percakapan Adyt Maulidimas (AMa) dan Ulfa Uphe Baros (UUB)

AMa : akhirnya real Madrid lolos $k$ babak 8 besarliga Champions,,,

UUB : alhamdulilah haha

Dari dialog atau teks di atas, secara situasi dan kondisi pengguna bahasa, mereka sama bahagia terhadap hasil yang di capai oleh Tim Sepak Bola kesayangan mereka ditandai dengan "akhirnya real Madrid lolos...." Kemudian dibalas dengan kalimat "Alhamdulillah" yang menandakan bahwa relasi hubungan pembicara merupakan teman akrab yang sama mempunyai hobby menonton permainan sepak bola. Makna yang dapat diambil dari luar teks yaitu ada peristiwa Olah Raga yang mereka ikuti secara bersama.Secara Patik atau kalimat basa-basi tidak ada diantara mereka. Interaksi dan komunikasi diantara laki-laki dan perempuan ternyata tidak menjadi penghalang dalam mempunyai Kegemaran atau Hobby yang sama. Mereka ternyata tidak menjadikan Gender sebagai pemutus jarak untuk kesamaan Hobby.

\section{Arky Drew Bieberz :mandi dulu ah.....atutu telat...hahhhaa}

Teks 3. atas nama akun Facebook Arky Drew Bieberz memang tidak ada tanggapan dan komentar dari teman atau pertemanan di akun Facebook. Unit analisis percakapan tidak ada, tetapi ada pertemanan yang menyukai komentar tersebut. Dengan meng Klik kata Like sehingga hanya ada respon pertemanan tanpa ada respon atau komentar melalui teks tulisan.

\section{Percakapan 4}

$\mathrm{AH}$ : pengen mati aja dhe rasanya :'( huaaaaaaaahiks

AS : napa sich dek? Lo km mati ga kasian ma kk mu Yg dsni, sepi ga da tmn lg dech.

DA : kl la pst masuk surge, dk papo kau mati, tp kl blm, Jgn !

AH : gubrak semua“... @_p Mkasih yg comment and like hihihi "

AS :youp !!!

Terjadi Komunikasi dan interaksi yang saling menanggapi diantara tiga orang tetapi siswa tersebut ada yang lain sekolah, hal tersebut ada indikasi yang dapat dilihat dari Nama Akun Facebook 'Agus Smansatexas' yang berarti siswa 
SMA Negeri 1 Bengkulu. Sedangkan Arthaz Hue merupakan siswi SMA N 2 Bengkulu Kelas $X \mathrm{H}$. Begitu juga atas nama akun Deko Aldifno bukan dari sekolah dan kelas yang sama tetapi diantara mereka sudah saling mengenal dan ada hubungan pertemanan. Kata "Pengen Mati aja" merupakan Ungkapan Perasaan Negatif yang di tulis dalam kalimat status, sehingga ada yang membaca dan memberi tanggapan secara langsung.Kata "Napa sich dek?" Sebuah pertanyaan yang di tuliskan dengan tujuan mendapatkan balasan langsung tetapi ternyata balasan "Gubrak semua" merupakan pilihan kata kurang tepat bila untuk menanggapi dari beberapa komentar tersebut karena pernyataan tersebut secara makna merupakan jawaban kekesalan pihak pertama, yang hanya menginginkan orang lain memberikan perhatian tanpa perlu tanggapan balasan. Sehingga pihak pertama dirasakan keegoannya terhadap orang lain. Kalimat tersebut juga ada ucapan "terima kasih" yang secara fungsinya untuk tanggapan secara keseluruhan tanpa ditujukan pada satu pihak saja.

\section{Ciri-Ciri Nonkebahasaan}

\section{a. Tanda Baca}

Tanda baca adalah yang tidak berhubungan dengan fonem pada suatu bahasa, melainkan berperan untuk menunjukkan struktur dan organisasi suatu tulisan.Kesimpulan utama dari data adalah tanda baca digunakan dengan masih dalam penggunaan standar tanpa melebihi aturan yang sebagaimana ditentukan dalam pedoman ejaan dan tanda baca.Tidak ditemukan data yang memodifikasi tanda baca atau manipulasi tanda baca untuk tujuan tertentu.

\section{b. Tanda Simbol}

Tanda simbol (Stiker's atau Emotion) merupakan lambang perasaan dan kondisi yang kadang kala digunakan di setiap kalimat status, seperti :

- (i) 'senyum

- :D 'senyum lebar

- =D 'tertawa lebar

- : $:$ 'sedih

- $\quad:{ }^{\prime}($ 'menangis

- $\quad$ :* 'cium

- $><$ 'marah

- $\quad$-__'sedih/murung

- ^_^ 'bahagia

\section{SIMPULAN}

Dari hasil penelitian maka diperoleh kesimpulan sebagai berikut: Ragam bahasa digunakan oleh siswa kelas X H SMA Negeri 2 Kota Bengkulu dalam media sosial Facebook. Terutama kosa kata bahasa ini digunakan oleh siswa yang sering mengupdate status di Facebook. Ragam bahasa dalam penelitian ini dapat dibagi menjadi 3 (tiga): (1) Tema (2) ciri kebahasaan dan (3) nonkebahasaan

Tema yang muncul cukup beragam, namun dalam arti lebih banyak Ungkapan Bernada Positif (91,6\%) yang terdiri dari: Interaksi, Interaksi Khusus, Ungkapan Kegiatan, Ungkapan Bijak, Ungkapan Perasaan, Ungkapan Perasaan Memancing Perhatian, Ungkapan Secara Khusus, dan Informasi. Sedangkan Ungkapan Perasaan Negatif (8,3\%). Demikian juga dengan identitas diri asli ( Status Akun Nama Asli) terdiri dari 19 orang siswa dengan persentase $(79,1 \%)$ 
dan sisanya 5 siswa dengan identitas samaran (Status Akun Nama Samaran) dengan persentase $(20,8 \%)$.

Ciri kebahasaan yang kerap muncul adalah penggunaan bahasa daerah, meski ada juga yang berbahasa Inggris. pemakaian bahasa itu bersifat aneka ragam (heterogen), keanekaragaman bahasa di atas Nampak dalam pemakaiannya secara dialog lisan yang dituliskan baik secara individu maupun kelompok. Ternyata setiap orang berbeda cara pemakaian bahasanya. Perbedaan itu dapat dilihat dari intonasi, pilihan katanya, susunan kalimatnya, cara mengungkapkannya dalam kalimat status di Facebook. Ternyata dari kalimat yang menyatakan sesuatu yang tertulis cepat sekali tanggapan dari teman-teman yang melihat dan membaca kalimat status pemilik akun tersebut, karena mereka sesama teman seumur atau sekelas, sehingga hanya merekalah yang memahami kalimat status tersebut, situasi kondisi, serta medium bicaranya.

Ciri nonkebahasaan ditandai dengan penggunaan ikon/simbol yang menggambarkan perasaan. Mereka sudah mengetahui makna dari simbol tersebut. Dengan adanya tanda atau simbol ( Stiker's atau Emoticon) akan mengakibatkan terjadinya interaksi, atau respon saling mengerti. Kesepakatan sosial diperlukan untuk dapat memaknai tanda tersebut.

Penulis menyadari bahwa penelitian mengenai ragam bahasa siswa kelas X H SMA Negeri 2 di Kota Bengkulu belum sempura dan terbuka untuk diadakan penelitian lanjutan. Baik mengenai penggunaan dan penulisan ragam bahasa siswa kelas $X \mathrm{H}$ SMA Negeri 2 Kota Bengkulu maupun bagian lain dari kalimat status yang ada dari Facebook tersebut.

Kiranya isyarat ini mampu menjadi pendorong bagi peneliti-peneliti yang lain untuk melanjutkannya, menggali lebih dalam atau mencari sesuatu yang baru dari ragam bahasa di Facebook, khususnya Kalimat Status atau akun Facebook yang digunakan di Kota Bengkulu. Semoga penelitian ini dapat bermanfaat bagi kita semua.

\section{DAFTAR PUSTAKA}

Azwar, Saifuddin. 2009. Metode Penelitian. Yogyakarta: Pustaka Pelajar.

Amir. 2009. Dasar-Dasar Penulisan karya ilmiah. Surakarta: Lembaga. Pengembangan Pendidikan (LPP) UNS dan UPT Penerbitan dan Percetakan UNS (UNS Press).

Brown, Gillian dan George Yule. 1996.( Di Indonesiakan oleh I. Soetikno) Analisis Wacana. Jakarta: Gramedia Pustaka Utama.

Cangara, Hafied. 2012. Pengantar IImu Komunikasi (Edisi Kedua). Jakarta: RajaGrafindo Persada.

Cangara, Hafied. .2010. Pengantar IImu Komunikasi (Edisi Revisi).Jakarta: RajaGrafindo Persada.

Chaer, Abdul dan Leonie Agustina.2004. Sosiolinguistik: Perkenalan Awal.Jakarta: PT. RinekaCipta.

Chaer, Abdul. 2010. Kesantunan Berbahasa. Jakarta: Rineka Cipta. 
Darma, Yoce Aliah. 2009. Analisis wacana Kritis. Bandung: CV Yrama Widya (Bekerja Sama dengan Jurusan Pendidikan Bahasa dan Sastra Indonesia (FPBS UPI Bandung).

Danim, Sudarwan. 2007. Metode Penelitian untuk IImu-IImu Perilaku. Jakarta: Bumi Aksara.

Depdikbud.1996. Kamus Besar Bahasa Indonesia.Jakarta: Depdikbud.

Djajasudarma, Fatimah. 2009. Semantik 2. Pemahaman Ilmu Makna. Bandung: Refika Aditama.

Emzir. 2011. Metodologi Penelitian Kualitatif: Analisis Data. Jakarta: RajaGrafindo Persada.

Ibrahim, Idi Subandy dan Bachruddin Ali Akhmad. 2011. Komunikasi dan Komodifikasi. Mengkaji Media dan Budaya dalam Dinamika Globalisasi. Jakarta: Yayasan Pustaka Obor Indonesia.

Junus, Husain dan Arifin Banasuru. 1996. Bahasa Indonesia. Tinjauan Sejarahnya dan Pemakaian Kalimat yang Baik dan Benar (Sebuah Analisis Teori Praktis). Surabaya: Usaha Nasional.

Keraf, Gorys. 2001. Diksi dan Gaya Bahasa. Jakarta: Gramedia.

Kridalaksana, Harimurti. 2009. Pembentukan Kata dalam Bahasa Indonesia. Jakarta: Gramedia Pustaka Utama.

Mulyana. 2005. Kajian Wacana. Yogyakarta: Tiara Wacana.

Nasution. 2006. Metode Research (Penelitian Ilmiah). Jakarta: Bumi Aksara.
Nababan, PWJ. 1993. Sosiolinguistik. Pengantar Awal.Jakarta: Gramedia.

Parera, J. D. 2009. Dasar-dasar Analisis Sintaksis. Jakarta: Erlangga.

Pateda, M. 1990. Sosiolinguistik. Bandung: Angkasa.

Sukardi. 2004. Metodologi Penelitian Pendidikan. Kompetensi dan Praktiknya.Jakarta: Bumi Aksara.

Sukardi. 2008. Metodologi Penelitian Pendidikan. Kompetensi dan Praktiknya.Jakarta:Bumi Aksara.

Susetyo. 2009. Menulis Akademik(Bahan Ajar). Bengkulu: Program Pascasarjana S-2 Pendidikan Bahasa Indonesia. Fakultas Keguruan dan Ilmu Pendidikan Universitas Bengkulu.

Tarigan, Hendry Guntur. 1994. Menulis Sebagai Suatu Keterampilan Berbahasa. Bandung: Angkasa.

Wibowo, Wahyu. 2003. Manajemen Bahasa. Jakarta: Gramedia Pustaka Utama. 